\title{
Collective Bargaining Laws, Threat Effects, and the Determination of Police Compensation
}

\section{Citation}

Ichniowski, Casey, Richard Barry Freeman, and Harrison Lauer. 1989. Collective Bargaining laws, threat effects, and the determination of police compensation. Journal of Labor Economics 7(2): 191-209.

\section{Published Version}

doi:10.1086/298205

\section{Permanent link}

http://nrs.harvard.edu/urn-3:HUL.InstRepos:4631949

\section{Terms of Use}

This article was downloaded from Harvard University's DASH repository, and is made available under the terms and conditions applicable to Other Posted Material, as set forth at http:// nrs.harvard.edu/urn-3:HUL.InstRepos:dash.current.terms-of-use\#LAA

\section{Share Your Story}

The Harvard community has made this article openly available.

Please share how this access benefits you. Submit a story.

Accessibility 


\title{
Collective Bargaining Laws, Threat Effects, and the Determination of Police Compensation
}

\author{
Casey Ichniowski, Columbia University and National \\ Burean of Economic Research
}

\section{Richard B. Freeman, Harvard University and National Bureau of Economic Research}

\section{Harrison Lauer, National Bureau of Economic Research}

This article demonstrates that state collective bargaining laws are important determinants of union and nonunion public employee compensation. State laws that provide stronger bargaining rights and ensure closure to the bargaining process increase the direct effect of police unions on compensation. Moreover, indirect threat effects on the pay of nonunion police also increase with stronger bargaining laws. In each law category investigated, nonunion police receive most of the compensation premium enjoyed by unionized police. Previous studies that have not adequately controlled for these effects of bargaining laws have therefore underestimated the full effect of public-sector unions on compensation.

\section{Introduction}

Several recent reviews of the literature on public sector union wage effects reach the common conclusion that "the 'average' effect of unionism in government . . . is roughly on the order of five percent . . smaller than the average union wage impact in private industry" (Lewin 1977, p. 138; also see Freeman 1986; Ehrenberg and Schwarz 1987; Lewis 1988). However, this conclusion may be misleading since studies of public-sector

\footnotetext{
[Journal of Labor Economics, 1989, vol. 7, no. 2]

(C) 1989 by The University of Chicago. All rights reserved.

0734-306X/89/0702-0004\$01.50
} 
union wage effects generally do not control for the effects of different state laws that regulate public-sector bargaining and the potential spillover of union wages to nonunion departments covered by those laws. Specifically, if laws favorable to collective bargaining raise pay in nonunion departments through "threat effects," two comparisons are needed to calculate the total effect of public-sector unions on compensation: the difference between union and nonunion pay within a given legal environment, and the difference between the pay in nonunion departments in that legal environment and the pay of nonunion employees in states with no provisions for public employee bargaining. These two components make up the full effect of unionism.

Existing research suggests that this type of analysis could be a promising avenue of inquiry. First, spillover effects across neighboring municipal governments and among departments in the same municipality are important determinants of public employee compensation (Ehrenberg and Goldstein 1975; Zax and Ichniowski 1988). Second, since the magnitude of threat effects on nonunion pay is related to the probability of unionization (Rosen 1969), studies that find that bargaining laws increase unionization propensities suggest that threat effects are larger in states with more favorable bargaining laws (Saltzman 1985, 1988; Ichniowski 1988). Finally, the few studies that have investigated the effects of bargaining laws on public employee pay have found significant cross-state differences associated with various bargaining laws (Olson 1980; Feuille and Delaney 1986; Freeman and Valletta 1988).

In this study we analyze data on municipal police departments to test whether bargaining laws increase the compensation of nonunion public employees and cause simple union/nonunion comparisons to underestimate the public-sector union wage effect. Empirical estimates from crosssection and longitudinal models show that police unions do have a much larger effect on compensation than is suggested by models that do not allow for threat effects associated with bargaining laws. Specifically, the pay of unionized police in states with compulsory interest arbitration laws is $15 \%-21 \%$ above the pay in nonunion departments in states without laws, while the pay of unionized police in states with duty-to-bargain statutes without arbitration provisions is $12 \%-16 \%$ above the pay of nonunion police in states without laws. Because nonunion police in duty-tobargain or arbitration states receive most of the wage increase that unions bargain for in their states, models that do not allow for threat effects on nonunion wages in these legal environments underestimate the total effect of unions on compensation.

\section{Theoretical Effects of Public-Sector Bargaining Laws on Pay in Nonunion Departments}

Unlike the federal-level regulation of collective bargaining in the private sector, state laws regulating collective bargaining by municipal government 
employees provide very different degrees of protection of bargaining rights. Union employees will clearly benefit directly from any law that increases the bargaining power of their union. ${ }^{1}$ Standard models of threat effects of unionization predict that spillover effects on the pay of nonunion employees will also be larger in states with more favorable bargaining laws. Specifically, let the probability of unionization be a function of state bargaining laws (Saltzman 1985, 1988; Ichniowski 1988) and the union wage differential: ${ }^{2}$

$$
p=p\left(W_{\text {diff }}, L\right), \quad p_{W_{\text {diff }}}>0, \quad p_{L}>0,
$$

where

$$
\begin{aligned}
W_{\text {diff }}= & \left(W_{u}-W_{n u}\right) / W_{n u} \text { with } W_{u} \text { the union wage and } W_{n u} \text { the nonunion } \\
& \text { wage before any threat effect is paid; and } \\
L= & \text { a variable measuring the amount of protection that state laws give } \\
& \text { to the collective bargaining process. }
\end{aligned}
$$

Managers in nonunion departments must recognize that lower wages increase the probability that the department will unionize and ultimately bargain for the union wage. For the case where the nonunion manager is minimizing the expected wage paid, Rosen (1969, pp. 192-93) derives the optimum wage response, $W_{n u}^{*}$, to the threat of unionism:

$$
W_{n u}^{*}=W_{u}+\frac{(1-p)}{\partial p / \partial W_{n u}} .
$$

From equation (2), $\partial W_{n u}^{*} / \partial p>0$, so that bargaining laws and other factors that increase the probability of unionism also raise nonunion wages, $W_{n u}^{*}$.

Bargaining laws should therefore increase the pay of unionized public employees by giving unions more bargaining power. They should also produce larger threat effects on nonunion employees' pay since they increase the likelihood of unionization. We test several specific predictions of this model. First, the more favorable the bargaining law, the more that

${ }^{1}$ In a traditional monopoly union framework, additional economic power provided by a law would enable a union to obtain larger wage increases by moving further up its labor demand curve. Under "efficient bargaining" models of union behavior, a law that gives a union more economic power would allow the union to reach higher indifference curves. As long as wages have a positive weight in the union's utility function, increased union power will be used to obtain higher wages.

${ }^{2}$ If more favorable bargaining laws increase the ability of unions to raise wages, and if this greater bargaining power increases employee demand for unionism more than it increases employer resistance to unionism, unionization propensities would increase under more favorable laws. Since the studies by Saltzman (1985) and Ichniowski (1988) do not consider differences in the union wage premium across states with different laws as a possible determinant of unionization, the effects of laws on unionization propensities in these studies may reflect the effects of laws on the ability of unions to raise compensation. 
union compensation will exceed compensation of unionized departments in states with no law. Second, the compensation of nonunion employees in states with a law guaranteeing at least some employee bargaining rights will be greater than the compensation of nonunion employees where there is no law; however, it should not exceed the compensation of union employees in the same law category. Depending on how large the indirect threat effects on nonunion pay are, nonunion compensation in a state with a protective law may be closer to union salaries in the same state than to nonunion salaries in states without laws. Therefore, the comparison of nonunion pay across states with different bargaining laws is as important as the comparison of union and nonunion pay within states with different laws. Finally, as a direct test of the relationship between nonunion pay and the threat of unionization, we analyze whether relatively low-paying nonunion departments are more likely to unionize than other nonunion departments.

\section{Data}

To perform cross-section and longitudinal analyses of the effect of bargaining statutes on union and nonunion police compensation, we collected data on police departments in 1965 and 1978 as described in the data Appendix. For 1978, the data cover approximately 800 police departments in municipalities with populations over 10,000 . The most recent year for which the union status data are available, 1978, corresponds to a year following a great deal of police unionization and changes in bargaining laws. Data for 1965 are available only for municipalities with populations above 25,000 , or a sample of somewhat less than 200 municipal police departments. In 1965, there were few police bargaining laws and little police unionization. Longitudinal wage change models for the 1965-78 period can be used to investigate the compensation effects of unionization and law variables since many states enacted laws and many departments unionized during this period.

\section{Dependent Compensation Variables}

For each year, we collected data on patrolmen's minimum and maximum salaries, the average salary in the police department, and two fringe benefit measures: per employee contributions to retirement systems and per employee contributions to health programs. A "total" compensation measure is defined as the sum of average salary and the two fringe benefits.

\section{Unionization}

In the public sector a written labor contract is a better indicator of the presence of the collective bargaining process than is a union local or association (Ehrenberg 1973). To measure whether police bargain, we use data from a 1979 survey we conducted that includes the following two questions: "Does your city have a written labor contract covering wages, hours, and conditions of employment for police personnel?" and "What 
year was the first written labor contract signed?" This survey was administered to all municipalities that report police department data in the 1978 Municipal Yearbook (see the Appendix). We conducted telephone interviews to obtain contract data for those nonrespondents that reported police salary data to avoid any bias that might result from systematic differences between respondents and nonrespondents. To construct the dummy variable that measures whether police department $i$ bargained in year $t, C_{i t}$, we assume that those cities that indicated that they had a collective bargaining agreement have been party to the contract continually since the year of their first agreement.

\section{Bargaining Laws}

To develop measures of the legal environment, we reviewed published information from annual volumes of Summary of Public Sector Labor Laws (U.S. Department of Labor), volumes prepared by the University of Hawaii Industrial Relations Center (Najita 1978), state statutes, and state court and state attorney-general opinions that also establish and modify the legal environment for public employee bargaining. To clarify inconsistencies among sources and to verify that the statutes and court opinions correspond to actual practice, we conducted telephone interviews with officials in state labor relations boards and agencies and with officials of municipal governments and their police unions.

Unlike previous studies that generally focus on simple dichotomous distinctions like the presence of a law or interest arbitration, we use these data to construct a hierarchical set of law categories measuring the degree to which laws protect employee bargaining rights and ensure closure to the bargaining process: no bargaining law (NL); bargaining-permitted statutes (BP) that allow employees to "present proposals" or to "meet and confer" but do not require employers to bargain; "duty-to-bargain" laws (DTB) that require employers to bargain but provide no compulsory interest arbitration mechanism; and duty-to-bargain laws with compulsory arbitration $(\mathrm{ARB}) .^{3}$

${ }^{3}$ For 1978 , the categories for the extent of bargaining rights as defined in state statutes or court opinions are "arbitration" (Alaska, Connecticut, Iowa, Massachusetts, Michigan, Minnesota, Nebraska, Nevada, New Jersey, New York, Pennsylvania, Rhode Island, Washington, Wisconsin), "duty-to-bargain" (Delaware, Florida, Hawaii, Maine, Montana, New Hampshire, Oregon, South Dakota, Vermont), "bargaining permitted" (California, Illinois, Indiana, Kansas, Louisiana, New Mexico, North Dakota, Ohio, Oklahoma), and "no law" (Alabama, Arizona, Arkansas, Colorado, Georgia, Idaho, Kentucky, Maryland, Mississippi, Missouri, North Carolina, South Carolina, Tennessee, Texas, Utah, Virginia, West Virginia, and Wyoming). For the few municipalities that have ordinances that differ from their state's collective bargaining law, the provisions in the municipal ordinance are used to categorize the legal environment. At the beginning of 1965, no states had police bargaining policies except California and North Dakota, with bargainingpermitted policies, and Rhode Island and Wisconsin, with duty-to-bargain policies. 
Before 1958, no state had a municipal employee bargaining law, and public sentiment regarding public employee bargaining-especially police bargaining-was hostile. Thus, the no-law environment has historically been a no-bargaining environment. ${ }^{4}$ Duty-to-bargain laws may give unions greater bargaining power than bargaining-permitted laws since they obligate employers to bargain with the police union.

However, obligating municipal employers to bargain does not ensure closure to the bargaining process because strikes by municipal police are illegal. ${ }^{5}$ In place of the right to strike, many states have enacted compulsory interest arbitration mechanisms ${ }^{6}$ for resolving collective bargaining impasses. Intrastate studies have found that the use of arbitration does not produce settlements that are any higher than negotiated settlements (see, e.g., Ashenfelter and Bloom 1984). However, this does not necessarily imply that arbitration has no effect on public employee compensation. Farber and Katz (1979) demonstrate that arbitrated and negotiated settlements will center around the expected award as arbitrator behavior becomes more predictable. A logical extension of their model in the context of this study is that pay in nonunion departments should not diverge too far from settlements that could be obtained through arbitration were they unionized. Therefore, to see if compensation in all union departments is raised by the availability of interest arbitration, we will compare compensation of union departments where duty-to-bargain laws do and do not have arbitration mechanisms. Then, to see if arbitration also raises pay of nonunion departments, we test whether the pay of nonunion departments in arbitration states more closely resembles the pay of union departments in the same state or the pay of non'inion departments where other laws exist.

\section{Control Variables}

Control variables that might also influence police compensation were collected for years as close as possible to the years for the police compensation data. Since bargaining laws are defined along state boundaries, it is particularly important to control for the effects of state-level characteristics that might indicate greater union strength or more favorable sentiments

${ }^{4}$ Because the absence of a municipal employee bargaining law has historically meant the absence of public employee bargaining, a small number of municipal observations in Missouri and North Carolina that outlaw police bargaining are included in the no-law category.

${ }^{5}$ In rare circumstances, a police strike might not be illegal. In Wisconsin, e.g., a police strike would be legal if both the employer and the police union waive interest arbitration in favor of a strike for resolving a bargaining impasse. In practice, this condition has never occurred.

${ }^{6}$ In the ARB category, we did not include those states that had a compulsory interest arbitration mechanism that does not extend to monetary issues (e.g., Maine) or states in which the arbitration mechanism is voluntary (e.g., Delaware). 
toward unionism. State-level variables include the percentage of a state's private-sector work force who are union members, ${ }^{7}$ membership of the American, Federation of State, County, and Municipal Employees (AFSCME) in the state as a percent of total state and local government employment, four geographic region dummy variables (northeast, north central, south, and west), and the percentage of a state's nonagricultural work force who are public employees. In addition to these controls for union support, we also control for "unobservable" variables that might be positively correlated with laws and police compensation in longitudinal compensation equations.

We also include several city-level variables to control for local labor market factors likely to influence police pay: population, per capita income, total municipal revenue per capita, and a central city dummy variable. Since public employee compensation varies with the form of local government (Ehrenberg 1973; Edwards and Edwards 1982), we also include three government-type dummy variables: council-manager, mayor-council, and commission. For a smaller sample of about 200 cities with populations above 25,000 , we have collected information on the salary paid to craft and kindred workers as an opportunity wage measure.

\section{Empirical Models and Estimates}

The discussion in Section II argues that compensation of unionized police will increase with more favorable bargaining laws and that the magnitude of the threat effect on the pay of nonunion police may also vary with the nature of the bargaining law. These propositions are first tested with the following cross-section model:

$$
\ln W_{i s}=a+\beta_{1}\left(C_{i} \times \overrightarrow{\mathrm{LAW}}_{s}\right)+\beta_{2} \overrightarrow{\mathrm{CITY}}_{i}+\beta_{3}{\overrightarrow{\mathrm{STATE}_{s}}}+\varepsilon_{i s},
$$

where

$W_{i s}=$ pay measure for municipality $i$ in state $s$;

$C_{i}=$ dummy variable for the presence of a labor contract;

$\underline{\mathrm{LAW}}_{s}=$ vector of categorical bargaining law variables;

$\overrightarrow{\mathrm{CITY}}_{i}=$ vector of municipal-level controls;

$\overrightarrow{\text { STATE }}_{s}=$ vector of state-level controls; and

$\varepsilon_{i s}=$ residual assumed $N(0, \sigma)$.

${ }^{7}$ The percent union data for 1960 that we use in the longitudinal equations refer to total percent unionized in the state and not percent unionized in the private sector (Troy and Scheflin 1985, pp. 7-4). However, since most public-sector unionization occurred after 1960, this measure should be very close to a privatesector percent unionized figure. 
The vectors of city- and state-level characteristics include variables that reflect support for and strength of unionism (e.g., percent union in the state, percent of public employees who are members of AFSCME), so that equation (3) measures the effect of the laws on union and nonunion compensation controlling for observable measures of union strength. ${ }^{8}$

Table 1 reports coefficients on the law $\times$ contract interactions when the comprehensive total compensation variable is used as the dependent variable. When any of the salary variables-average departmental salary, patrolman's entrance salary, or patrolman's maximum salary-are used as the dependent variable, estimated coefficients on all contract $\times$ law variables are very similar to those for the total compensation equation. ${ }^{9}$ The estimates show that the direct effect of unions on compensation rises with the strength of the bargaining law: the contract $\times$ law coefficients increase from .09 in the no-law category to .21 in the arbitration category.

However, the difference between the contract $X$ arbitration coefficient and the contract $X$ duty-to-bargain coefficient is a modest .048 and of marginal statistical significance. An $F$-test rejects the equality of these two coefficients at the .146 level of significance. In similar equations (which we do not report in table 1) that use the various salary measures as the dependent pay variable, we find that the magnitude (and the level of significance as judged by an $F$-test) of the difference in these two coefficients

${ }^{8}$ In our analyses we treat state-level bargaining laws as exogenous to the municipal compensation determination process for police. Farber's analysis (1988) of the determinants of public-sector bargaining laws finds that the timing of the passage of state laws is not well explained by economic characteristics of the state and its work force and supports the notion that bargaining laws are the result of factors exogenous to the system of variables considered in the compensation determination models of this study. Saltzman's case studies of the enactment of public-sector bargaining laws in Illinois and Ohio (1988) also find that these laws were largely the result of "idiosyncratic" political developments. Furthermore, there is also the possibility of a selectivity relating unionism and wages in the context of our model. Nonunion departments paying low wages are more likely to become unionized, which would lead to an underestimate of the effect of collective bargaining in crosssection compensation equations. Since simultaneous systems of wage and unionization equations using cross-section data have generally been unsuccessful (see Freeman and Medoff 1981; Lewis 1986), we do not attempt to estimate any endogenous systems of wage and police unionism equations.

${ }^{9}$ When we estimated equations that used fringe benefits per employee and the ratio of fringe benefits to total compensation as dependent variables, we found that only in the bargaining-permitted law category does bargaining have a relatively larger effect on fringe benefits per employee than on average salary. Therefore, in the other law categories, the coefficients on the contract variable are similar in an average salary equation and in a total compensation equation. While this might suggest that public-sector unions do not generally have a larger effect on fringe benefits than on salaries as they do in the private sector (Freeman 1981), it may also be that laws dictate the contributions of union and nonunion employers to the insurance and retirement benefits used in this study. 
Table 1

The Effects of Bargaining Laws on Union and Nonunion Police Compensation

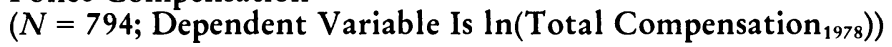

\begin{tabular}{|c|c|}
\hline & Cross-Section Estimates \\
\hline 1a. Contract $\times$ arbitration & $\begin{array}{l}.211^{* * *} \\
(.033)\end{array}$ \\
\hline b. No contract $\times$ arbitration & $\begin{array}{l}.202^{* * *} \\
(.077)\end{array}$ \\
\hline 2a. Contract $\times$ duty to bargain & $\begin{array}{l}.163^{* * *} \\
(.030)\end{array}$ \\
\hline b. No contract $X$ duty to bargain & $\begin{array}{l}.119^{* * *} \\
(.049)\end{array}$ \\
\hline 3a. Contract $\times$ bargaining permitted & $\begin{array}{l}.155^{* * *(F)} \\
(.025)\end{array}$ \\
\hline b. No contract $\times$ bargaining permitted & $\begin{array}{l}.098^{* * *} \\
(.027)\end{array}$ \\
\hline 4a. Contract $\times$ no law & $\begin{array}{l}.094^{*} \\
(.064)\end{array}$ \\
\hline$R^{2}$ & .632 \\
\hline \multicolumn{2}{|c|}{$\begin{array}{l}\text { NOTE.-Standard errors are in parentheses. Other controls: Municipal-level control } \\
\text { variables are natural logarithms of total revenue per capita, income per capita, and pop- } \\
\text { ulation; and dummy variables for central city and for three types of government structure. } \\
\text { State-level control variables are percent of the state work force that is unionized and that } \\
\text { is in public employment, and AFSCME membership in the state as a percent of public } \\
\text { employment. }(F) \text { indicates that the coefficient on the contract } * \text { law interaction variable is } \\
\text { significantly different from the no-contract* law interaction variable in the same law category } \\
\text { at the } 10 \text { level as judged by an } F \text {-test. } \\
{ }^{*} \text { Significance at the } 10 \text { level using a one-tailed } t \text {-test. } \\
{ }^{* * *} \text { Significance at the } .01 \text { level using a one-tailed } t \text {-test. }\end{array}$} \\
\hline
\end{tabular}

is $0.044(.157)$ in the average salary equation, $0.055(.019)$ in the patrolman's maximum salary equation, and $0.060(.008)$ in the patrolman's minimum salary equation. Taken together, these results suggest that arbitration produces only a small, marginally significant increase in salaries of about $5 \%$.

The cross-section estimates also imply that the indirect threat effect of unions on nonunion police salaries increases as bargaining laws become more favorable. They imply a rising threat effect because the difference between the point estimates of the no contract $X$ law coefficient and contract $\times$ law coefficient decreases as laws become more favorable. The differences in the point estimates of the coefficients on the contract and no contract variables are 0.009 in the ARB category, 0.044 in the DTB category, 0.057 in the BP category, and .094 in the no-law category. Only in the bargaining permitted and no-law categories are the contract/no-contract differentials significantly different from zero. ${ }^{10}$ In the DTB and ARB cat-

${ }^{10}$ While the significance of the difference between the contract and no-contract states in the no-law category is given by the $t$-statistic for the contract $\times$ no-law coefficient, the statistic for comparing the $\mathrm{BP} \times$ contract and $\mathrm{BP} \times$ no-contract coefficients in this equation is $F(1,774)=3.74$. The equality of the two coefficients can be rejected at the .05 level. 
egories, the spillover effects estimated in this model are so large that there is no significant difference between union and nonunion salaries. In every law category, nonunion police compensation is closer to the pay of unionized police in their own states than to the compensation of nonunion police in no-law states. The cross-section equations thus indicate that as bargaining laws become more favorable, police unions have more power to raise compensation, and a larger share of the union compensation premium spills over to nonunion departments.

A related interpretation of these results is that the more favorable laws induce increases in the percentage of police departments that are unionized, which is an intervening variable that affects union and nonunion pay. There is support for this interpretation. Specifically, in 1978 the percentage of a state's police departments that were unionized was, on average, $98.9 \%$ for states with arbitration laws, $71.7 \%$ for states with duty-to-bargain laws, $37.1 \%$ for states with bargaining-permitted laws, and $15.0 \%$ for states without laws. When a state-level variable measuring the percent of police departments that have contracts and the municipal-level contract variable replace the contract $\times$ law interactions in the table 1 equation, the coefficient on the "percent of police departments with contracts" variable is 0.286 and significant at the .01 level, while the coefficient on the contract variable is -0.012 and not significantly different from zero. As the laws appear to be instrumental in the development of formal bargaining relationships for police and other occupations (Saltzman 1985, 1988; Ichniowski 1988), we prefer to interpret the laws as the key exogenous variables and interpret the percent of police departments under contract as an intervening variable that serves as the route by which laws affect union and nonunion police compensation. In short, the results are consistent with a path model in which laws induce unionism, which in turn increases union bargaining power and the magnitude of the union threat effect. ${ }^{11}$

\section{Longitudinal Compensation Model and Results}

The 1978 cross-section pay equations in table 1 present a consistent picture of how police unionism affects compensation, but they may omit some important state-level factor that determines pay and that is correlated with the nature of the bargaining laws. To account for this possible bias, we estimate a longitudinal wage-change model. Specifically, we allow for an omitted city-specific effect and rewrite the cross-section equation for period $1(1978)$ as

\footnotetext{
${ }^{11}$ As one might expect from these results, collinearity diagnostics in the "variance decomposition matrix" and the associated condition indices (see Belsley, Kuh, and Welsch 1980, pp. 85-191) for a regression equation that includes the law variables and the variable for the percent of police departments under contract reveal a clear case of what Belsley et al. term "competing dependency" collinearity between the percent union and the law $\times$ contract interaction terms.
} 


$$
\ln W_{1}=\alpha_{1}+\beta_{1} \vec{X}_{1}+\mu_{1}+v_{1}
$$

where

$$
\begin{aligned}
\varepsilon_{1} & =\mu_{1}+v_{1} ; \text { and } \\
\vec{X}_{1}= & \text { a vector of state- and municipal-level control variables that includes } \\
& \text { the contract and law variables. }
\end{aligned}
$$

The term $\mu_{1}$ is the omitted city-specific effect, so that while $E\left(\mu_{i s} \cdot \mathrm{LAW}\right)$ $\neq 0, E\left(v_{i s} \cdot \mathrm{LAW}\right)=0$. Next we assume that the omitted variable also affects compensation in the earlier period (period 0 ) according to

$$
\ln W_{0}=\alpha_{0}+\beta_{0} \vec{X}_{0}+\mu_{0}+v_{0}
$$

In equation (5), we allow for the omitted variable to have a different effect in the two time periods by assuming that $\mu_{0}=\mu_{1} / \lambda$. If $\lambda=1$, then the effect of the omitted variable would be the same in both periods. Subtracting equation (5) from equation (4) and rearranging terms, one obtains

$$
\begin{aligned}
\ln W_{1}= & \left(\alpha_{1}-\lambda \alpha_{0}\right)+\lambda \ln W_{0}+\beta_{1}\left(\vec{X}_{1}-\vec{X}_{0}\right) \\
& +\left(\beta_{1}-\lambda \beta_{0}\right) \vec{X}_{0}+\left(v_{1}-\lambda v_{0}\right) .
\end{aligned}
$$

In this longitudinal model, the 1978 pay variable is a function of pay in 1965 , the levels of the control variables in 1965, and the changes in the control variables between 1965 and 1978. By rearranging terms, a complete set of "law-change" variables with the following coefficients can be introduced into equation (6):

$$
\begin{array}{r}
\beta_{\mathrm{ARB}, 78} \cdot\left(\mathrm{NL}_{65} \rightarrow \mathrm{ARB}_{78}\right)+ \\
\beta_{\mathrm{DTB}, 78} \cdot\left(\mathrm{NL}_{65} \rightarrow \mathrm{DTB}_{78}\right)+ \\
\beta_{\mathrm{BP}, 78} \cdot\left(\mathrm{NL}_{65} \rightarrow \mathrm{BP}_{78}\right)+ \\
\left(\beta_{\mathrm{BP}, 78}-\lambda \beta_{\mathrm{BP}, 65}\right) \cdot\left(\mathrm{BP}_{65} \rightarrow \mathrm{BP}_{78}\right)+ \\
\left(\beta_{\mathrm{ARB}, 78}-\lambda \beta_{\mathrm{DTB}, 65}\right) \cdot\left(\mathrm{DTB}_{65} \rightarrow \mathrm{ARB}_{78}\right) .
\end{array}
$$

Other than states that remained in the no-law category between 1965 and 1978, these are the only five law changes that occurred between 1965 and 1978. Of particular interest then are the coefficients on the first three lawchange variables (i.e., $\mathrm{NL}_{65} \rightarrow \mathrm{ARB}_{78}, \mathrm{NL}_{65} \rightarrow \mathrm{DTB}_{78}$, and $\mathrm{NL}_{65} \rightarrow \mathrm{BP}_{78}$ ) that are unbiased estimates of the effects of the arbitration, duty-to-bargain, and bargaining-permitted laws on wages in 1978. The coefficients on the other two law-change variables measure to some extent how much the different law coefficients themselves changed between 1965 and 1978. 
However, these coefficients may still be biased estimates of the effects of the laws on compensation in 1978. Specifically, a correlation between the error term in equation (6) and $\ln W_{0}$ will bias the estimate of $\lambda$ downward. This in turn would cause an upward bias on the law coefficients if there is a positive partial correlation between $\ln W_{1}$ and $\ln W_{0}$. However, the magnitude of this upward bias on the coefficients on the law-change variables will be small if there is little systematic relationship between prior period wages and the enactment of laws. Specifically, the partial correlations between the law-change variables and the 1965 pay variable enter the formula for correcting this bias (Griliches and Ringstadt 1971, p. 197). We estimated these partial correlations from statistics obtained from a regression of 1965 wages on the law change variables and all other control variables used in the wage-change regressions. Since all of these partial correlations are less than .02, the upward biases on the law-change coefficients are small. We therefore report only unadjusted coefficients obtained from estimating equation (6) by ordinary least squares.

\section{Results}

The sample for the equation (6) model contains only 163 municipalities since the 1965 data are available only for municipalities with populations above 25,000 . Before estimating the longitudinal model, we reestimate the cross-section model for this reduced sample since the sample is different from the larger sample used in table 1 in systematic ways. With the smaller sample, some of the law $\times$ contract cells are empty or nearly empty, so that we cannot estimate the cross-section equation with a complete set of interactions. ${ }^{12}$ Instead, we estimate a model with three law variables and a single contract variable that forces the contract/no-contract compensation difference to be the same in all law categories. Cross-section results for 1978 for this smaller sample of larger cities are presented in column 1 of table $2 .{ }^{13}$ The results in table 2 , column 1 , are similar in most respects to the cross-section results for the larger sample in table 1 . However, in this smaller sample of larger cities, the point estimate of the bargaining-permitted coefficient is slightly larger than the coefficient on the duty-tobargain variable, largely because the duty-to-bargain coefficient in table 2 is somewhat smaller than either of the duty-to-bargain coefficients in the table 1 equation. Union and nonunion pay are again similar in the smaller table 2 sample with the coefficient on the contract variable only .019 and not significantly different from zero. Union and nonunion departments both enjoy the compensation effects associated with the laws in their states.

\footnotetext{
${ }^{12}$ In the $n=163$ sample, there are no observations in the no-contract $\times$ arbitration cell, one observation in the no-contract $X$ duty-to-bargain cell, and one observation in the contract $\times$ no-law cell.

${ }^{13}$ In table 2 we again report estimates from equations using total compensation as the dependent variable. Results for the table 2 models are similar when the table 2 models are reestimated using the various salary measures as the dependent variable.
} 
Table 2

The Effects of Bargaining Laws and Unionization on Police

Compensation, Cross-Section and Longitudinal Models

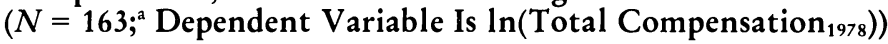

\begin{tabular}{lcc}
\hline & $\begin{array}{c}\text { Cross-Section } \\
\text { Model }\end{array}$ & $\begin{array}{c}\text { Longitudinal } \\
\text { Model }\end{array}$ \\
\hline 1. Contract & .019 & $\ldots$ \\
2a. Arbitration & $(.052)$ & $\ldots$ \\
b. Duty to bargain & $.175^{* *}$ & $\ldots 3)$ \\
c. Bargaining permitted & $.089^{*}$ & $\ldots$ \\
3. Contract gainers & $(.068)$ & $\ldots$ \\
4a. No law to arbitration & $\left(.05^{* *}\right.$ & $\ldots$ \\
b. No law to Duty-to-Bargain & $\ldots$ & -.007 \\
c. No law to Bargaining Permitted & $\ldots$ & $(.052)$ \\
5. In (total compensation & & $\left..158^{* *}\right)$ \\
& $\ldots$ & $(.084)$ \\
$R^{2}$ & $\ldots$ & $.126^{* *}$ \\
\end{tabular}

NOTE.-Standard errors are in parentheses. Control variables in cross-section model are those listed in the note of table 1 and the median earnings of craft and kindred workers. Control variables in the longitudinal model are changes in the natural logarithms of total revenue per capita, income per capita, population, and salary of craft and kindred workers; the levels of these three variables in base-year period; changes and base-year levels of percent union in the private sector in the state and the percent of all state and local employees in the state belonging to AFSCME. Variables that are available for only one time period or that do not change over time are entered as levels: region dummy variables; central city dummy variable; city government type dummy variables; and the percentage of the state work force in public employment.

a This sample includes only those municipalities with populations above 25,000 .

* Significance at the .10 level using a one-tailed $t$-test.

** Significance at the .05 level using a one-tailed $t$-test.

Column 2 of table 2 presents estimates from the longitudinal equation (6) model that controls for omitted city-specific effects. Compensation in states that enacted arbitration or duty-to-bargain laws between 1965 and 1978 increased significantly more for both union and nonunion workers than did the compensation in states that remained in the no-law category. The only effect in the table 2 , column 1 , cross-section equation that appears to be attributable to omitted variable bias is the impact of bargainingpermitted laws on compensation. Consistent with the insignificant coefficient on the contract variable in the cross-section equation of column 1 for this smaller sample, those municipalities that gained a contract over the 1965-78 period did not experience any additional pay premium above that associated with being in a state that enacted a law (see table 2, col. 2, line 3 ).

The results from the longitudinal model thus provide additional support that bargaining laws, other than the bargaining-permitted statutes, increase the power of unions to raise police compensation. Furthermore, nonunion 
departments again appear to capture virtually all of the compensation increases through threat effects, as compensation in nonunion departments in states that enact arbitration or duty-to-bargian laws increase as much as compensation in union departments. Gaining a contract yields no significant increase in compensation above the effect of the laws.

\section{Hazard Probability Analysis of the Union Threat Effect}

The cross-section and longitudinal analyses indicate that direct and indirect effects of police unions on compensation increase with more favorable bargaining laws. The theoretical model also predicts that nonunion cities that do not raise pay to avoid unionization face a greater risk of becoming unionized in subsequent periods. To directly test whether relatively lowpaying nonunion departments are more likely to unionize in subsequent periods, we estimate the following hazard function:

$$
\operatorname{pr}\left(C_{78}=1 \mid C_{77}=0\right)=H\left(\text { relative or expected } \text { compensation }_{77}\right),
$$

where $\operatorname{pr}\left(C_{78}=1 \mid C_{77}=0\right)$ is the probability that a department that was nonunion at the end of 1977 will unionize during 1978, and $H$ is the hazard function determining unionization rates. We use the residuals from the basic cross-section compensation equation in table 1 to measure whether a department is relatively low paid at the end of $1977 . .^{14}$ These residuals, which we standardize and express in $z$-score units, measure whether a department's compensation is above or below expected compensation after accounting for the effects of the compensation determinants in the model. This variable, DEVCOMP, will be negatively correlated with unionization if nonunion departments with relatively low compensation at the end of 1977 are more likely to unionize during 1978.

This analysis is a strong test of whether unionization propensities are affected by the relative compensation in nonunion departments for three reasons. First, the department must unionize during a 1-year period after it perceives itself to be relatively underpaid (i.e., DEVCOMP is negative). Second, if the compensation in nonunion cities in this sample is high enough to remain nonunion, there may not be enough variation in DEVCOMP among nonunion departments to affect unionization propensities. Third, nonunion cities that, according to the DEVCOMP residuals, are low paying in 1978 may have also been low-paying nonunion cities in prior years. That is, because of some omitted variable, the DEVCOMP residuals for 1978 are correlated with the residuals that would have been calculated from earlier periods' compensation equations. Since our estimating equation for unionization during 1978 will not include the omitted variable that makes this particular sample of nonunion cities particularly resistant

${ }^{14}$ According to the Municipal Yearbook, the salary and compensation data refer to the pay levels in effect on January 1, 1978. 
to unionization, the estimated effects on the DEVCOMP variable will be biased toward zero.

To test directly whether nonunion cities face an increased threat of unionization when they pay lower compensation, we estimate a logistic equation to test whether DEVCOMP affects the probability of unionizing during 1978 for the sample of 354 police departments that entered 1978 as nonunion departments. Since equation (2) allows laws to affect the probability of unionization independent of any effect that laws have on unionization through compensation, the law variables are included among the control variables in the hazard probability equation. We also interact DEVCOMP with the law variables to test whether relatively low pay affects unionization propensities differently in the four law categories.

The results in lines $1 \mathrm{a}-1 \mathrm{~d}$ of table 3 indicate that relatively low-paid nonunion municipalities are more likely to unionize in the ARB and $\mathrm{BP}$ categories. This effect does not exist in the DTB or NL categories. One possible explanation for the insignificant effect of low salaries on unionization propensities in the DTB category is that the few departments in DTB states that were still nonunion in 1978 were all paying a large enough threat effect to remain nonunion. ${ }^{15}$ These results indicate that in two law categories relatively low compensation in nonunion departments significantly increases the chance of being unionized, while in one law category there is no evidence of this relationship.

The coefficients of the law variables in lines $2 a-2 c$ indicate that, even in 1978 , after the majority of municipalities in the ARB and DTB categories had already unionized, laws still have a significant positive effect on the unionization propensities of the remaining nonunion municipalities. Evaluated at the mean unionization propensity of $13 \%$ in 1978 , these logistic coefficients indicate that the unionization rates among ARB, DTB, and BP municipalities were $75.0,55.7$, and 25.4 percentage points, respectively, above the unionization propensity of NL municipalities.

\section{Conclusion}

The results of this study show that public-sector bargaining laws have significant effects on the compensation of union and nonunion employees. Models that do not allow for these effects present an incomplete picture of how public-sector unionism influences compensation and underestimates the total effect of police unions on compensation. Considered by themselves, the effects of arbitration and duty-to-bargain laws on compensation can be viewed as undesirable from the taxpayer's perspective. However, duty-to-bargain laws, especially those that provide for interest arbitration,

${ }^{15}$ There are only 21 nonunion observations in the DTB category, while in the $\mathrm{BP}$ category there are 121 nonunion observations. The average value of the DEVCOMP variable is smaller in absolute value among the DTB cities than it is among $\mathrm{BP}$ cities (i.e., -0.0008 and -0.0011 , respectively). 
Table 3

The Effects of Bargaining Laws and Low Salaries on the Probability of Unionizing during 1978

$\left(\right.$ Dependent Variable $=\operatorname{Pr}\left(\right.$ Contract $\left.\left._{1978}\right) ; N=354^{\mathrm{a}}\right)$

\begin{tabular}{lc}
\hline & Coefficients \\
\hline 1a. Arbitration $\times$ DEVCOMP & $-1.251^{* *}$ \\
b. Duty to bargain $\times$ DEVCOMP & $(.717)$ \\
& .220 \\
c. Bargaining permitted $\times$ DEVCOMP & $(.739)$ \\
& $-.572^{* *}$ \\
d. No law $\times$ DEVCOMP & $(.342)$ \\
2a. Arbitration & .572 \\
b. Duty to bargain & $(.755)$ \\
& $\left(1.694^{* * *}\right.$ \\
c. Bargaining permitted & $4.426)$ \\
& $\left(1.083^{* * *}\right.$ \\
-2 $\times$ log likelihood & $1.313^{*}$ \\
\end{tabular}

NOTE.-Asymptotically normal standard crrors are in parentheses. Other controls are those listed in the note of table 1.

a The sample includes only those municipalities that still had nonunion police departments at the end of 1977.

* Significance at the .10 level using a one-tailed $t$-test.

** Significance at the $.05 \mathrm{level}$ using a one-tailed $t$-test.

*** Significance at the .01 level using a one-tailed $t$-test.

reduce illegal strike activity by police (Ichniowski 1982). Only by weighing the costs of higher pay and the benefits of uninterrupted police protection can the overall effect of these laws on citizen welfare be measured.

\section{Data Appendix}

Data used in 1978 cross-section compensation and salary equations were collected from the following sources. International City Management Association, Municipal Yearbook, 1978, (Washington, D.C.: International City Management Association, 1978), sec. E2, pp. 160-209, reports: police personnel, salary and wage expenditures, city contributions to retirement and health insurance benefits, and entrance and maximum salaries. Municipal Yearbook, 1978, table 1/1, pp. 8-44, reports: 1975 population, total city revenue, form of local government, and per capita income. The International City Management Association's "MUNL" computer data file for 1978 identifies central cities. To categorize states' police bargaining laws, we reviewed J. Najita, Guide to Statutory Provisions in Public Sector Collective Bargaining (University of Hawaii, Industrial Relations Center, 1978); annual volumes of U.S. Department of Labor, "Summary of Public Sector Labor Relations Policies," (Washington, D.C.: Government Printing Office); and state statutes, court opinions, and opinions of attorneys general. Data on police collective bargaining contracts are from our own 1979 survey of police departments and from telephone interviews with departments that did not respond to this 
survey. Leo Troy and Neil Scheflin, Union Sourcebook: Membership, Structure, Finance, Directory, 1985 (West Orange, N.J.: Industrial Relations Data Information Services, 1985), table 7.6, pp. 7-8, report the percent of the state's private-sector work force that is organized in 1975. U.S. Bureau of the Census, 1970 Census of Population, vol. 1, Characteristics of the Population, pts. 2-52, reports: public-sector employment by state in table 56, and median earnings of male craft and kindred workers in tables 89 and 105. The opportunity wage measure is available only for cities with populations above 25,000 and is therefore used only in the table 2 cross-section and longitudinal pay equations. Gregory Saltzman provided us with state-specific figures for 1977 on AFSCME membership as a percent of public employment, which he describes in his "Bargaining Laws as a Cause and a Consequence of Teacher Unionism," Industrial and Labor Relations Review 38, no. 3 (April 1985): 335-51.

Additional variables in the 1965-78 compensation change equation (table 2, col. 2) are from the following sources. International City Management Association, Municipal Yearbook, 1965 (Chicago: International City Management Association, 1965), table 15, pp. 428-53, reports the compensation and salary measures. The Municipal Yearbook, 1965, table II-A, pp. 42-53, reports 1960 population and total city revenue. U.S. Bureau of the Census, County and City Data Book, 1967 (Washington, D.C.: Government Printing Office, 1967) reports income per capita. U.S. Bureau of the Census, 1960 Census of the Population, vol. 1, Characteristics of the Population, pts. 2-52, Table 86, reports median earnings of male craft and kindred workers. Troy and Scheflin (1985), table 7.2, pp. 7-4, report the percent of the state's work force that is organized in 1960. Saltzman provided the state figures on percent of public employees who are members of AFSCME in 1964.

\section{References}

Ashenfelter, Orley, and Bloom, David. "Models of Arbitrator Behavior: Theory and Evidence." American Economic Review 74 (March 1984): 111-24.

Belsley, David; Kuh, Edwin; and Welsch, Roy. Regression Diagnostics: Identifying Influential Data and Sources of Collinearity. New York: Wiley, 1980.

Edwards, Linda N., and Edwards, Franklin R. "Public Unions, Local Government Structure, and the Compensation of Municipal Sanitation Workers." Economic Inquiry 20 (July 1982): 405-25.

Ehrenberg, Ronald G. "Municipal Government Structure, Unionization, and the Wages of Fire Fighters." Industrial and Labor Relations Review 27 (October 1973): 36-48.

Ehrenberg, Ronald G., and Goldstein, Gerald S. "A Model of Public Sector Wage Determination." Journal of Urban Economics 2 (April 1975): 22345.

Ehrenberg, Ronald G., and Schwarz, Joshua L. "Public Sector Labor Markets." In Handbook of Labor Economics, edited by Orley Ashenfelter and Richard Layard. Amsterdam: North-Holland, 1987. 
Farber, Henry S. "The Evolution of Public Sector Bargaining Laws." In When Public Sector Workers Unionize, edited by Richard B. Freeman and Casey Ichniowski, pp. 129-66. Chicago: University of Chicago Press, 1988.

Farber, Henry S., and Katz, Harry C. "Interest Arbitration Outcomes and the Incentive to Bargain." Industrial and Labor Relations Review 33 (October 1979): 55-63.

Feuille, Peter, and Delaney, John T. "Collective Bargaining, Interest Arbitration, and Police Salaries." Industrial and Labor Relations Review 39 (January 1986): 228-40.

Freeman, Richard B., "The Effects of Unionism on Fringe Benefits." Industrial and Labor Relations Review 34 (July 1981): 489-509.

Freeman, Richard B. "Unionism Comes to the Public Sector." Journal of Economic Literature 24 (March 1986): 41-86.

Freeman, Richard B., and Medoff, James L. "The Impact of Collective Bargaining: Illusion or Reality?" In U.S. Industrial Relations, 1950-1980: A Critical Assessment, edited by Jack Stieber, Robert B. McKersie, and D. Quinn Mills, pp. 47-98. Madison, Wis.: Industrial Relations Research Association, 1981.

Freeman, Richard B., and Valletta, Robert. "Does the Legal Environment Affect Public Sector Labor Markets?" In When Public Sector Workers Unionize, edited by Richard B. Freeman and Casey Ichniowski, pp. 81103. Chicago: University of Chicago Press, 1988.

Griliches, Zvi, and Ringstadt, V. Economies of Scale and the Form of the Production Function. Amsterdam: North Holland, 1971.

Ichniowski, Casey. "Arbitration and Police Bargaining: Prescriptions for the Blue Flu." Industrial Relations 21 (Spring 1982): 149-66.

- "Public Sector Union Growth and Bargaining Laws: A Proportional Hazards Approach with Time-varying Treatments." In When Public Sector Workers Unionize, edited by Richard B. Freeman and Casey Ichniowski, pp. 19-38. Chicago: University of Chicago Press, 1988.

Lewin, David. "Public Sector Labor Relations." Labor History 18 (Winter 1977): 433-43.

Lewis, H. Gregg. Union Relative Wage Effects: A Survey. Chicago: University of Chicago Press, 1986.

- "Union/Nonunion Wage Gaps in the Public Sector." In When Public Sector Workers Unionize, edited by Richard B. Freeman and Casey Ichniowski, pp. 169-93. Chicago: University of Chicago Press, 1988.

Najita, J. Guide to Statutory Provisions in Public Sector Collective Bargaining. (Honolulu: University of Hawaii, Industrial Relations Center, 1978).

Olson, Craig. "The Impact of Arbitration on the Wages of Firefighters." Industrial Relations 19 (Fall 1980): 325-39.

Rosen, Sherwin. "Trade Union Power, Threat Effects, and the Extent of Organization." Review of Economic Studies 36 (April 1969): 185-96.

Saltzman, Gregory. "Bargaining Laws as a Cause and a Consequence of Teacher Unionism." Industrial and Labor Relations Review 38 (April 1985): 335-51.

—_. "Public Sector Bargaining Laws Really Matter: Evidence from 
Ohio and Illinois." In When Public Sector Workers Unionize, edited by Richard B. Freeman and Casey Ichniowski, pp. 41-78. Chicago: University of Chicago Press, 1988.

Troy, Leo, and Scheflin, Neil. Union Sourcebook: Membership, Structure, Finance, Directory, 1985. West Orange, N.J.: Industrial Relations Data Information Services, 1985.

U.S. Department of Labor. "Summary of Public Sector Labor Relations Policies." Washington, D.C.: Government Printing Office, various years. Zax, Jeffrey, and Ichniowski, Casey. "The Effects of Public Sector Unionism on Pay, Employment, Department Budgets, and Municipal Expenditures." In When Public Sector Workers Unionize, edited by Richard B. Freeman and Casey Ichniowski, pp. 323-61. Chicago: University of Chicago Press, 1988. 